\title{
Interaksi Kapang Patogen Fusarium oxysporum dengan Bakteri Kitinolitik Rizosfer Tanaman Jahe dan Pisang
}

\author{
Rejeki Siti Ferniah $^{1 *}$, Sri Pujiyanto ${ }^{1)}$,Susiana Purwantisari ${ }^{1)}$ dan Supriyadi $^{1)}$ \\ Jurusan Biologi, Fakultas Matematika dan Ilmu Pengetahuan Alam, Universitas Diponegoro, Semarang 50275
}

Diterima 11-03-2009Ｄisetujui 06-06-2011

\begin{abstract}
Fusarium oxysporum is a pathogenic fungi for many plants. The fungi have chitin cell wall that can be degraded by chitinase from chitinolytic bacteria. Aim of this research is determine how the interaction between the bacteria and F.oxysporum. Bacteria were isolated from plant rizosfere. Chitinolytic activity were measured based on the clear zone around the colony in chitin medium. Bacteria and fungi interaction were determined by an antagonistic test. This research showed that there were 9 chitinolytic bacteria. J4 and P3 had high chitinolytic index, that are 3 and 3.33, respectively. The two isolates antagonist to Foxysporum, which the bacteria prevent growth of the fungi. The J4 and P3 are alternative biofungicide for F.oxysporum.
\end{abstract}

Keywords: chitinolytic bacteria, Fusarium oxysporum f.sp zingiberi, interaction

\section{PENDAHULUAN}

Kendala utama produksi tanaman obat maupun hortikultur Indonesia adalah penyediaan bibit unggul dan serangan hama/penyakit tanaman. Penyakit yang banyak menyerang komoditas tanaman Indonesia adalah penyakit layu bakteri, busuk rimpang, dan bercak daun. Penyakit layu bakteri disebabkan oleh bakteri Ralstonia solanacearum, busuk rimpang disebabkan oleh kapang Fusarium oxysporum, dan bercak daun disebabkan oleh Alternaria solani.

Kapang Fusarium merupakan salah satu kapang patogen tanaman yang sulit dikendalikan (Singh et al. 1999). Kapang ini merupakan patogen tanaman yang penting secara ekonomi karena dapat menyebabkan busuk dan layu pada akar, batang maupun kecambah pada lebih dari 100 jenis tanaman. Genus ini terdiri atas berbagai spesies, yaitu F.oxysporum, F.affine, F.culmorum, F.dimerum, F.graminearum, F.moniliforme, F.radicicola, F.roseum, F.solani, dan Fusarium sp. F.oxysporum mempunyai beberapa varietas tergantung pada jenis tanaman inangnya. Beberapa varietas F.oxysporum dan inangnya adalah F.oxysporum f.sp. cubense pada pisang, F.oxysporum f.sp. lycopersici pada tomat, dan F.oxysporum f.sp. zingiberi pada jahe (Gonsalves \& Ferreira 1994). Fusarium oxysporum yang menyerang tanaman menyebabkan busuk rimpang yang ditandai dengan layu dan menguningnya daun dan berujung pada kematian tanaman sebelum panen.

*Telp: +628122889064

Email: ferniah_mikro@yahoo.com
Kitin merupakan senyawa utama yang menyusun dinding sel kapang, khususnya Fusarium (Fakamizo et al. 1996). Pengembangan teknologi yang cocok untuk mengendalikan kapang tersebut adalah pemanfaatan mikroba kitinolitik yang memiliki aktivitas kitinase. Mikroba kitinolitik mampu menghidrolisis senyawa kitin yang merupakan struktur dinding sel kapang patogen. Terdegradasinya senyawa tersebut menyebabkan kapang patogen menjadi lemah atau mati. Dengan demikian mikroba kitinolitik berpotensi digunakan sebagai biofungisida untuk mengendalikan kapang patogen yang memiliki kitin sebagai struktur dinding selnya.

Bakteri kitinolitik merupakan mikroba yang memiliki kemampuan mendegradasi kitin karena memiliki enzim kitinase. Berbagai kelompok bakteri seperti Streptomyces (Saito et al. 1999), Bacillus (Mitsutomi et al. 1995), Aeromonas (Ueda et al. 1996), Serratia (Krishnan et al. 1999), Enterobacter (Chernin et al. 1995), Pseudomonas (Wang et al. 1997), Arthrobacter (Okazaki et al. 1999, Pujiyanto 2002), dan Vibrio (Svitil et al. 1997), dilaporkan memiliki aktivitas kitinolitik.

Penelitian tentang eksplorasi bakteri kitinolitik indigenous Indonesia telah dilakukan oleh Pujiyanto et al. (2002), yang berhasil mengisolasi 55 isolat bakteri kitinolitik dari Ekosistem Air Hitam Kalimantan Tengah. Hasil pengujian secara in vitro diperoleh dua isolat bakteri yang memiliki kemampuan menghambat pertumbuhan kapang patogen Rhizoctonia solani dan Helmintosporium oryzae. 
Isolasi bakteri kitinolitik dari berbagai tanah pertanian di Jawa Tengah dilakukan oleh Pujiyanto et al. (2004), dan Ferniah et al. (2004), yang memiliki kemampuan menghambat dengan kuat pertumbuhan kapang Alternaria solani dan Fusarium oxysporum yang menyerang tanaman kentang. Interaksi antara bakteri kitinolitik dan kapang patogen tanaman mungkin spesifik bagi tiap kapang dan bakteri.

Berbagai laporan menyebutkan bahwa bakteri kitinolitik sangat potensial digunakan dalam bidang pertanian sebagai agen biokontrol yang efektif terhadap sejumlah kapang fitopatogenik. Bakteri kitinolitik Aeromonas caviae digunakan untuk mengontrol serangan Rhizoctonia solani dan Fusarium oxysporum pada kapas serta Sclerotium rolfsii pada buncis. Enzim kitinase yang dihasilkan oleh Serratia marcescens juga efektif untuk melawan kapang patogen $S$. rolfsii. Filtrat kultur Aphanocladium terbukti menghambat pertumbuhan Necteria haematcocca yang menyerang kapri. Mikroba kitinolitik Streptomyces dan Paenibacillus juga dilaporkan dapat mengendalikan kapang Fusarium yang menyerang mentimun (Singh et al. 1999). Bakteri genus Pseudomonas dapat mengendalikan beberapa jenis Fusarium, antara lain P.fluorescens dapat melawan F.oxysporum dan P.dispersa dapat melawan F.udum (Singh et al. 1999 \& Gohel et al. 2004 dalam Gohel et al. 2005). Bakteri kitinolitik juga dapat berperan sebagai biokontrol terhadap serangga hama. Mubarik et al. (2010), menemukan dua isolat Bacillus dari rizosfer tanaman cabai yang memiliki kemampuan menghidrolisis eksoskeleton serangga Bemisia tabaci.

Bakteri kitinolitik berdasarkan penelitian Pujiyanto et al. (2002), Ferniah et al. (2004), dan Hartantinningsih (2004), dapat ditemukan pada rizosfer tanaman sehat. Bagaimanakah interaksi antara bakteri kitinolitik rizosfer tanaman dengan kapang F.oxysporum? Penelitian ini bertujuan mendapatkan isolat bakteri kitinolitik dan mengetahui interaksinya terhadap kapang F.oxysporum. Manfaat aplikatif penelitian ini adalah untuk menentukan strategi pengendalian F.oxysporum secara alami sehingga kegagalan panen akibat kapang tersebut dapat diminimalisasi.

\section{BAHANDANMETODE}

Isolat bakteri kitinolitik diperoleh dari rizosfer tanaman jahe dan pisang di daerah Tembalang, Semarang. Kapang Fusarium oxysporum diisolasi dari tanaman jahe di daerah Magelang. Medium yang dibutuhkan adalah medium potato dextrose agar (PDA) dan kitin agar.

Isolasi dan Seleksi Bakteri Kitinolitik. Bakteri kitinolitik diisolasi dari $1 \mathrm{~g}$ tanah pertanian lokal, dengan cara mensuspensikannya dalam $100 \mathrm{ml}$ larutan garam fisiologis steril. Sebanyak $1 \mathrm{ml}$ suspensi ditebar dalam cawan petri yang sudah diisi medium kitin agar. Inkubasi dilakukan pada suhu $27^{\circ} \mathrm{C}$ selama 48 jam. Isolat kitinolitik ditandai dengan adanya daerah halo (zona bening) di sekitar koloni. Seleksi dilakukan dengan cara mengukur indeks kitinolitik yang dimiliki masing-masing isolat. Indeks kitinolitik merupakan nilai perbandingan antara diameter daerah halo dan diameter koloni. Isolat-isolat dengan indeks kitinolitik tinggi diinteraksikan terhadap kapang Fusarium oxysporum.

Interaksi Bakteri Kitinolitik dan Fusarium oxysporum. Isolat-isolat kitinolitik terpilih dan kapang Fusarium oxysporum ditumbuhkan bersama dalam medium PDA dengan metode biakan ganda. Isolat bakteri diinokulasikan ke dalam medium PDA secara taburan, dan satu potong koloni kapang ditumbuhkan di tengah medium dalam satu cawan petri. Biakan diinkubasi selama 120 jam dalam suhu kamar. Pertumbuhan kapang diukur setiap hari dibandingkan dengan kontrol. Kontrol yang digunakan adalah medium berisi koloni kapang dengan diameter sama dengan pada perlakuan, tanpa isolat bakteri.

\section{HASIL DAN PEMBAHASAN}

Bakteri kitinolitik berhasil diisolasi dari rizosfer tanaman jahe dan pisang yang sehat. Tempat pengambilan sampel berada di Kelurahan Tembalang, Semarang, dengan karakteristik tanah berlempung dan lembap. Rizosfer yang diambil adalah berjarak tidak lebih dari $30 \mathrm{~cm}$ di sekeliling tanaman. Sebanyak 5 isolat bakteri kitinolitik diperoleh dari rizosfer jahe dan 4 isolat bakteri kitinolitik diperoleh dari rizosfer tanaman pisang (Tabel 1).

Tabel 1 Hasil Isolasi Bakteri dan Pengujian Aktivitas Kitinolitik

\begin{tabular}{|c|c|c|c|c|}
\hline Kode isolat & Asal isolat & Zona bening $(\mathrm{mm})$ & Diameter koloni (mm) & Rasio zona bening \\
\hline $\mathrm{J} 1$ & Tembalang & 15 & 9 & 1,66 \\
\hline $\mathrm{J} 2$ & Tembalang & 7 & 6 & 1,16 \\
\hline $\mathrm{J} 3$ & Tembalang & 27 & 17 & 1,58 \\
\hline $\mathrm{J} 4$ & Tembalang & 16 & 4 & 4 \\
\hline J5 & Tembalang & 7 & 5 & 1,40 \\
\hline P1 & Tembalang & 24 & 12 & 2 \\
\hline $\mathrm{P} 2$ & Tembalang & 24 & 20 & 1,20 \\
\hline P3 & Tembalang & 26 & 6 & 4,33 \\
\hline $\mathrm{P} 4$ & Tembalang & 10 & 5 & 2 \\
\hline
\end{tabular}




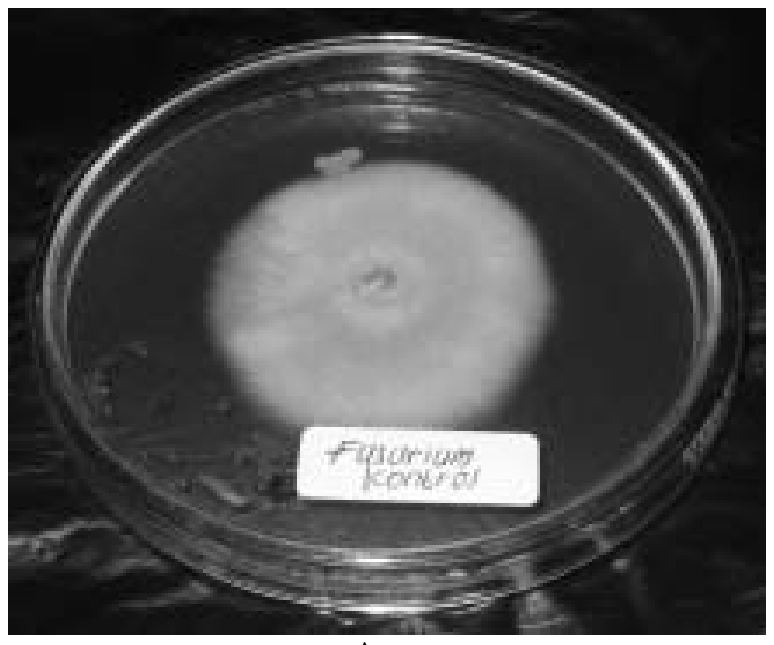

A

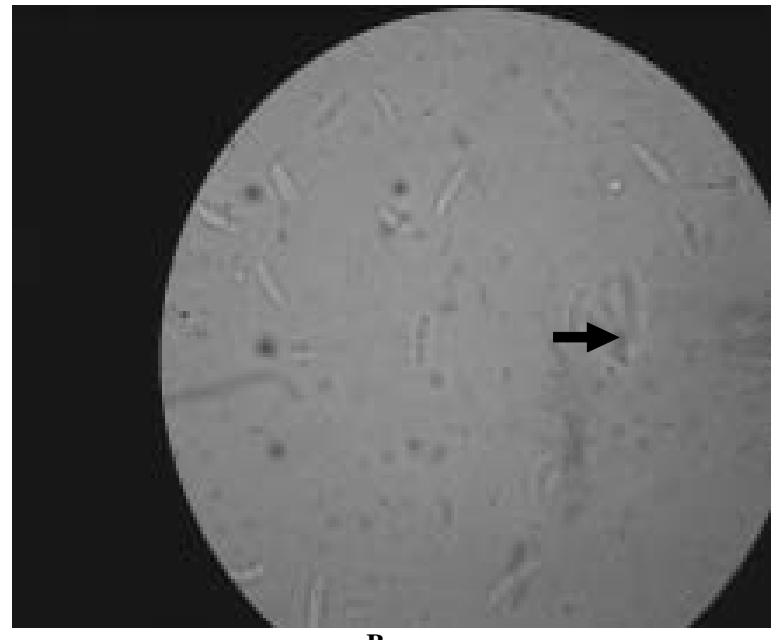

B

Gambar 1 Morfologi Fusarium oxysporum: a. Koloni kapang umur 5 hari; b. Makrokonidia berbentuk bulan sabit bersepta

Tabel 2 Perbandingan diameter kapang yang ditumbuhkan bersama Bakteri Kitinolitik pada Hari ke-5 dengan Kontrol Kapang Fusarium oxysporum

\begin{tabular}{ccc}
\hline No. & Kode isolat & Diameter kapang $(\mathrm{mm})$ \\
\hline 1. & Kontrol fusarium & 51 \\
2. & $\mathrm{~J} 4$ & 14 \\
3. & P3 & 14 \\
\hline
\end{tabular}

Isolat J4 dari rizosfer jahe dan P3 dari rizosfer pisang dipilih untuk digunakan dalam uji interaksi terhadap kapang. Pemilihan isolat dilakukan berdasarkan nilai aktivitas hidrolisis kitin. Aktivitas hidrolisis kitin tertinggi dari bakteri rizosfer jahe dimiliki oleh J4. Isolat dari rizosfer pisang dengan aktivitas hidrolisis kitin tertinggi adalah P3.

Kapang berhasil diisolasi dari tanaman jahe yang berada di Magelang, dengan kondisi tanah yang lembap. Gambar 1 menunjukkan morfologi kapang Fusarium oxysporum. Koloni kapang berwarna merah jambu dengan miselium muda berwarna putih. Makrokonidia kapang ini berbentuk khas, yaitu seperti bulan sabit dan bersekat-sekat (bersepta).

Hasil interaksi bakteri-kapang ditunjukkan pada Tabel 2. Pengukuran terhadap diameter kapang menunjukkan adanya hambatan pertumbuhan kapang jika kapang ini ditumbuhkan bersama bakteri kitinolitik.

Gambar 2 menunjukkan bahwa isolat J4 dan P3 mempunyai aktivitas katalitik yang sama terhadap Fusarium oxysporum. Kedua isolat menyebabkan hambatan pertumbuhan sehingga pada hari ke-5 diameter koloni hanya mencapai sepertiga dari pertumbuhan normal. Interaksi bakteri-kapang sampai dengan hari ke-5 menunjukkan adanya zona bening di sekitar koloni kapang (Gambar 3). Hal ini mengindikasikan bahwa di daerah zona bening terjadi kompetisi antara bakteri dan kapang, tetapi kitin pada miselium kapang didegradasi oleh bakteri yang tumbuh di sekitar kapang.

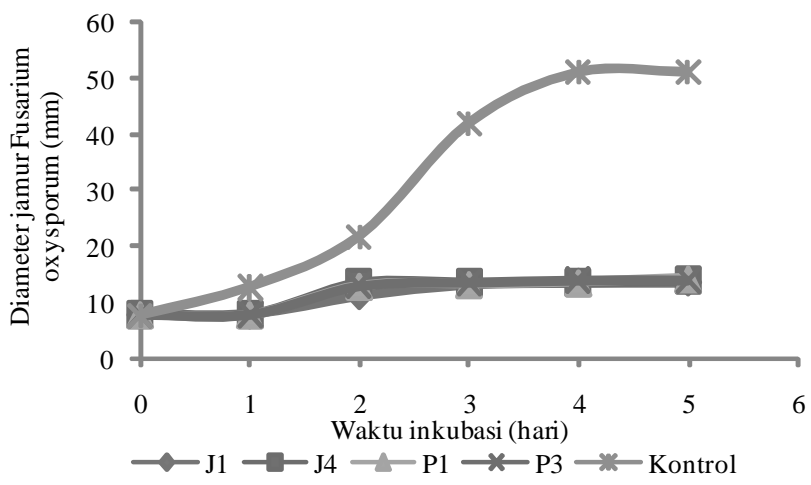

Gambar 2 Pertumbuhan jamur Fusarium oxysporum yang diuji dengan bakteri kitinolitik pada inkubasi selama 5 hari

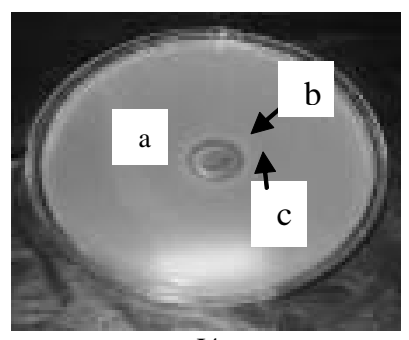

$\mathrm{J} 4$

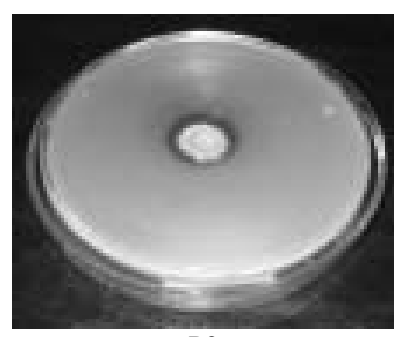

$\mathrm{P} 3$
Gambar 3 Interaksi bakteri kitinolitik dan Fusarium oxysporum pada inkubasi hari ke-5. a. Isolat bakteri kitinolitik, b. Zona bening, c. Fusarium oxysporum

Hasil uji antagonisme tersebut menunjukan interaksi antara jamur F. oxysporum dengan bakteri kitinolitik, dimana miselium jamur $F$. oxysporum yang diuji dengan bakteri kitinolitik cenderung tumbuh serong ke atas (menjauhi media), tetap berwarna putih dan miseliumnya tumbuh lebih panjang jika dibandingkan dengan miselium kontrol (Gambar 4). Hal ini disebabkan oleh adanya bakteri kitinolitik pada media yang mampu menghasilkan enzim kitinase yang dapat menghambat dan mengganggu proses pertumbuhan jamur $F$. oxysporum. Pertumbuhan miselium yang cenderung serong ke atas (menjauhi media) selain merupakan mekanisme pertahanan diri untuk menghindari bakteri 


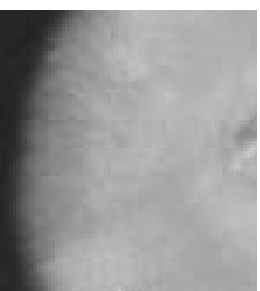

A

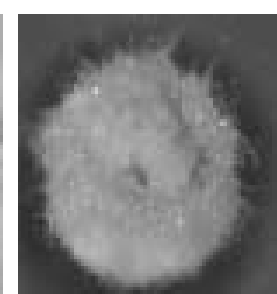

B

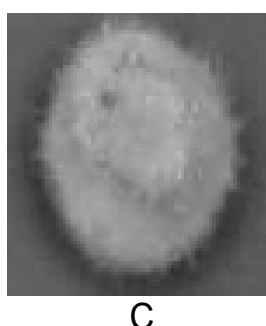

C
Gambar 4 Pertumbuhan miselium Fusarium oxysporum setelah berinteraksi dengan bakteri kitinolitik. a. kontrol, b. jamur yang diuji dengan isolat bakteri J4, c. jamur yang diuji dengan isolat bakteri P3

kitinolitik juga dilakukan untuk mencari oksigen yang ada di udara.

Bakteri kitinolitik dapat mendegradasi kitin karena menghasilkan enzim kitinase. Enzim kitinase disintesis secara induktif, yaitu hanya akan dihasilkan jika ada senyawa kitin sebagai indusernya. Hasil degradasi kitin berupa senyawa $\mathrm{N}$ asetil $\mathrm{D}$ glukosamin selanjutnya digunakan sebagai sumber nutrisi bagi bakteri, sehingga bakteri tumbuh lebih cepat menutupi zona bening yang semula terbentuk. Bakteri kitinolitik terus tumbuh memblokade pertumbuhan kapang Fusarium oxysporum.

Interaksi antara bakteri kitinolitik dan kapang berdinding sel kitin merupakan interaksi yang menguntungkan bagi bakteri kitinolitik tetapi merugikan bagi kapang. Bakteri menghasilkan senyawa bioaktif yang dapat merusak komponen struktural kapang. Adanya enzim hidrolitik, misalnya kitinase pada bakteri kitinolitik, mampu mendegradasi kitin penyusun dinding sel kapang. Yurnalisa, 2001, melaporkan bahwa kitinase kasar mampu menghambat perkecambahan konidia Fusarium oxysporum secara in vitro. Singh et al. 1999, juga menunjukkan bahwa kitinase dari Streptomyces mampu melisiskan dinding sel dan menghambat pertumbuhan Fusarium oxysporum.

Hasil interaksi bakteri-kapang pada penelitian ini menunjukkan bahwa bakteri kitinolitik dapat menjadi musuh alami bagi kapang Fusarium oxysporum. Suatu biofungisida bagi kapang ini dapat dibuat menggunakan bahan dasar bakteri-bakteri kitinolitik.

\section{SIMPULAN}

Interaksi bakteri-kapang menguntungkan bagi bakteri kitinolitik tetapi merugikan kapang Fusarium oxysporum. Bakteri kitinolitik memanfaatkan kitin pada dinding sel miselium kapang untuk didegradasi dan hasil degradasinya digunakan sebagai sumber nutrisi bagi pertumbuhan bakteri. Kapang terhambat pertumbuhannya karena miselium tidak dapat terbentuk dengan baik.

\section{UCAPANTERIMAKASIH}

Ucapan terima kasih disampai kpada Dirjen Dikti yang telah membiayai melalui Hibah penugasan penelitian Desentralisasi No. 321/SP2H/PP/DP2M/III/2008. Terima kasih kepada semua pihak yang telah terlibat dalam penelitian ini.

\section{DAFTARPUSTAKA}

Chernin, L., Ismailov, Z., Haran, S. \& Chet, I. 1995. Chitinolytic patogens. Appl. Environ. Microbiol 61: 1720-1726.

Fakamizo, T., Honda, Y., Toyoda, H., Ouchi, S. \& Goto, S. 1996. Chitinous component of cell wall of Fusarium oxysporum, its structure deduced from chitosanase digestion.. Biosci Biotech Biochem 60: 1705-1708.

Ferniah, R.S, Pujiyanto, S. \& Purwantisari, S. 2004. Potensi bakteri kitinolitik sebagai agen pengendali kapang Fusarium oxysporum penyebab penyakit busuk batang tanaman kentang. Seminar Nasional Hasil Pertanian. Yogyakarta.

Gohel, V., Singh, A., Vimal, M., Ashwini, P. \& Chhatpar, H.S. 2005. Bioprospecting and antifungal potential of chitinolytic microorganisms. African Journal of Biotechnology 5(2): 54-72.

Gonsalves, A.K. \& Fereira, SA. 1994. Fusarium Primer, http// ww w. Extento.hawaii.edu/kbase/crop/Type/ fusarium_primer.htm.

Hartantinningsih, Y. 2004. Penapisan bakteri kitinolitik tanah pertanian yang berpotensi sebagai pengendali jamur patogen. Laporan Kerja Praktek. UNDIP, Semarang.

Krishnan, H.B., Kim, K.Y. \& Krishnan, A.H. 1999. Expression of Serratia macescens chitinase gene in Sinorhizobium fredii USDA 191 and S. meliloti RCR 201 impedes soybean and alfalfa nodulation. MPMI 12: 48-751.

Mitsutomi, M., Kidoh, H., Tomita, H. \& Watanabe, T. 1995. The action of Bacillus circulans WL-12 chitinases on partially N-acetylated chitosan. Biosc.i Biotech. Biochem 59: 529-531.

Okazaki, K., Kawabata, T. Nakano, M. \& Hayakawa, S. 1999. Purification and properties of chitinase from Arthrobacter sp. NHB-10. Biosci. Biotech. Biochem 63: 1644-1646.

Mubarik, N.R, Mahagini, I, Anindyaputri, A., Santoso, S. \& Rusmana, I. 2010. Chitinolytic Bacteria Isolated from Chili Rhizosphere: Chitinase Characterization and Its Application as Biocontrol for Whitefly (Bemisia tabaci Genn.). American $J$ of Agricultural and Biological Sciences 5(4): 430-435.

Pujiyanto, S. 2002. Isolasi dan karakterisasi bakteri kitinolitik serta kloning shotgun gen kitinase dari Ekosistem Air Hitam, Kalimantan Tengah. Tesis, IPB, Bogor. Ferniah, R.S. dan Purwantisari, S. 2004. Uji Antagonisme bakteri kitinolitik sebagai agen pengendali kapang Alternaria solani penyebab penyakit bercak daun tanaman kentang. Seminar Nasional Hasil Pertanian. Yogyakarta.

Pujiyanto, S., Ferniah, R.S. \& Purwantisari, S. 2004. Uji Antagonisme bakteri kitinolitik sebagai agen pengendali kapang Alternaria solani penyebab penyakit bercak daun tanaman kentang. Seminar Nasional Hasil Pertanian. Yogyakarta.

Saito A., Fujii, T., Yoneyama, T., Redenbach, M., Onho, T., Watanabe, T. \& Miyashita, K. 1999. High-multiplicity of chitinase genes in Streptomyces coelicolor A3(2). Biosci. Biotech. Biochem 63: 710-718.

Svitil, A.L., Chadhain, S.M., Moore, J.A. \& Kirchman, D.L. 1997. Chitin degradation proteins produced by the marine bacterium Vibrio harveyi growing on different forms of chitin. Appl Environ Micobiol 63: 408-413.

Singh, P.P., Shin, Y.C., Park, C.S. \& Chung, Y.R. 1999. Biological control of Fusarium wilt of cucumber by chitinolitic bacteria. Phytopathology 89: 92-99.

Ueda, M., Shiro, M. Kawaguchi, T. \& Arai, M. 1996. Expression of chitinase III gen of Aeromonas 10S-24 in E. coli. Biosci. Biotech. Biochem 60: 1195-1197. Enterobacter agglomerans, antagonistic to fungal plant 
Wang, S.L., Chiou, S.H. \& Chang. W.T. 1997. Production of chitinase from shellfish waste by Pseudomonas aeruginosa K187. Proceed. Nat. Sci. Council ROC 21: 71-78.
Yurnalisa. 2001. Kajian peran aktinomisetes kitinolitik dalam pengendalian jamur patogen Fusarium oxysporum skala laboratorium. Tesis. UGM, Yogyakarta. 